\title{
Implantação da Mini Rede em Incubadora: Relato de Caso
}

\author{
Nisivoccia, Patricia; Bova, Rosangela \\ Hospital Geral de Pedreira — patricia.silva@pedreira.org.br
}

Introdução: Cuidado humanizado e seguro é a filosofia da assistência em um hospital público da zona sul de São Paulo com número médio de 270 partos por mês, referência em gestação de alto risco e com elevado número de nascimento de prematuro. o desenvolvimento do recém nascido de alto risco fora da vida uterina se inicia em geral dentro de uma unidade de terapia intensiva. para isso é importante a utilização de métodos de humanização como a mini rede, que tem a característica de minimizar o impacto do nascimento prematuro e reproduzir características do ambiente uterino, aquecendo o recém-nascido poupando energia para ganho de peso, diminuir o stress e melhorar os parâmetros vitais para auxilio na estabilidade clinica e alta precoce. a técnica consiste na confecção em tecido macio, com temas infantis de uma rede semelhante a do adulto, onde permanece fixa na incubadora onde o recém-nascido é acomodado mesmo sob ventilação mecânica, onde o critério de inclusão no protocolo é a estabilidade clinica. Objetivos: Relatar experiência exitosa na implantação da mini rede na incubadora relacionada à melhora clinica do recém nascido. Métodos: Esse estudo consistiu em um relato de experiência da implantação da mini rede na incubadora na unidade de terapia intensiva neonatal. Resultados: o estudo objetivou avaliar os efeitos da implantação do novo protocolo de mini rede, minimizando o impacto do nascimento prematuro, redução da dor, melhora no padrão de sono, redução do stress evidenciado com a expressão facial relaxada, ofertando uma assistência humanizada. Conclusões: Analisando retrospectivamente a escala de NIPS e os parâmetros vitais antes e após a implantação da mini rede em incubadora, verificamos que com o novo protocolo a escala de dor e parâmetros vitais apresentou acentuada melhora nos seus valores, evidenciando ausência de dor e respectivamente satisfação dos pais ao observarem a expressão fácil de tranquilidade e bem estar. Assim podemos dizer que o protocolo implantado auxiliou no ganho ponderal, pois fornece o calor necessário e limites para seu desenvolvimento.

Nisivoccia, Patricia; Bova, Rosangela. Implantação da Mini Rede em Incubadora: Relato de Caso. In: Anais do Congresso Internacional de Humanidades \& Humanização em Saúde [= Blucher Medical Proceedings, num.2, vol.1]. São Paulo: Editora Blucher, 2014. ISSN 2357-7282 DOI 10.5151/medpro-cihhs-10797 